\title{
GOD, THE MEANING OF LIFE, AND A NEW ARGUMENT FOR ATHEISM
}

Jason Megill and Daniel Linford

\begin{abstract}
We raise various puzzles about the relationship between God (if God exists) and the meaning of life (if life has meaning). These difficulties suggest that, even if we assume that God exists, and even if (as we argue) God's existence would entail that our lives have meaning, God is not and could not be the source of the meaning of life. We conclude by discussing implications of our arguments: (i) these claims can be used in a novel argument for atheism; (ii) these claims undermine an extant argument for God's existence; and (iii) they suggest that atheism is consistent with our lives having meaning.
\end{abstract}

\section{INTRODUCTION}

In the literature on the meaning of life over the last few decades, the "meaning of life" is generally taken to be some positive feature of an individual's life that is distinct from (though perhaps related to) other positive features (wellbeing, happiness, etc.) that a life might or might not have. It is also typically thought that lives can have meaning to varying degrees, so e.g., one life might be more meaningful than another, or the same life might be more or less meaningful at different times. We follow these conventions. ${ }^{1}$

Some philosophers have endorsed the view that God is somehow the source of the meaning of life and moreover, God's existence is necessary for life to have meaning. For example, some claim "that God has a plan for the universe and that one's life is meaningful to the degree that one helps God realize this plan" (Metz 2013: section 2.1). ${ }^{2}$ Some have argued that our lives would be meaningless without an objective moral code, and only God could provide

\footnotetext{
1 See Metz (2013) for a discussion of the meaning of life literature and these conventions (which Metz endorses).

$2 \quad$ See Alcoff (2007) for a defense of this view. See also Brown (1971), Levine (1987) and Cottingham (2003) for more on this view.
} 
Penultimate Draft. Please cite the version forthcoming in the International Journal for Philosophy of Religion.

such a code (see Craig (1994)); some claim that without God, our lives would be "contingent" and therefore meaningless (see, e.g., Haber (1997)); while still others claim "that our lives would have meaning only insofar as they were intentionally fashioned by a creator, thereby obtaining meaning of the sort that an art-object has (Gordon (1983))" (Metz 2013: section 2.1). Of course, objections have been raised to these views, and there are secular accounts of the meaning of life; nevertheless, the God-based approach has been and still is prominent in the philosophical literature on the meaning of life. ${ }^{3}$

This paper concerns the relationship between God and the meaning of life. We argue for the following two conditional claims: (1) if God exists, then all lives have meaning. However, (2) if any life has meaning, then God is not the source of this meaning (even if God exists); i.e., God-based approaches to the meaning of life are problematic. ${ }^{4}$ God's existence would guarantee that our lives have meaning, and so the existence of God is a sufficient condition for life having meaning, though God could not be the source of this meaning, so God is not a necessary condition for life having meaning.

3 And God-based approaches to the meaning of life have been endorsed by many non-philosophically oriented theists. The view has also been held by some philosophically oriented non-theists. Kahane (2013: 2) claims that "Russell thought that, in the absence of God, we must build our lives on 'a foundation of unyielding despair."' Albert Camus (1955) is arguably another example.

For secular accounts of the meaning of life, see, e.g., Nozick (1981), Wolf (1997), Bond (1983), and Singer (1993: Chapter 12).

4 To be precise, there are numerous possibilities: it might be that only some lives have meaning. Or perhaps all lives have meaning, though what gives life meaning might vary across individuals; i.e., why assume that there is only one meaning that life can have? Perhaps the meaning of one life is not the same as the meaning of another life? Or maybe a given life has meaning at some times but not others? Or perhaps the meaning that a given life has might change over time? To be clear, when we say that God could not be the source of the meaning of life, we mean that any time a particular life has meaning, whatever that meaning might be, God is not the reason. 


\section{IF GOD EXISTS, THEN OUR LIVES HAVE MEANING}

In this section, we argue that if God - understood here as the God of classical theism - exists, then our lives must have meaning, whatever it might be.

Consider the following argument:

(1) If God exists, then God is all-knowing, all-powerful, and all-good.

This premise is true by definition; it is simply the definition of "God" endorsed by many classical theists. ${ }^{5}$ Furthermore,

(2) If God is all-good, all-knowing, and all-powerful, then no lives are meaningless.

The God of classical theism, a perfect being, would not create beings that have a meaningless existence. To clarify, recall that in the extant literature, it is generally agreed that lives can have different degrees of meaning; for example, one person's life might be more meaningful than another's. So more precisely, (2) claims that if God is omniscient, omnipotent and omnibenevolent, then no individual human life is completely devoid of meaning, even if a given life might have less meaning than another life. First, note that (2) is consistent with theism; the theist can simply hold that God exists, that (2) is true, and therefore, no lives are meaningless. Likewise, (2) is consistent with atheism; the atheist can claim that if God exists, life would have

$5 \quad$ See, e.g., Wainwright (2012: Introduction),

The object of attitudes valorized in the major religious traditions is typically regarded as maximally great. Conceptions of maximal greatness differ but theists believe that a maximally great reality must be a maximally great person or God. Theists largely agree that a maximally great person would be omnipresent, omnipotent, omniscient, and all good. They do not agree on a number of God's other attributes, however. 
Penultimate Draft. Please cite the version forthcoming in the International Journal for Philosophy of Religion.

meaning, yet still deny that God exists, whether they think life has meaning or not. So, clearly this premise does not beg the question against either theism or atheism.

Second, the Anselmian God is (i) omniscient, and so would know whether or not human life would have meaning in a given possible world, (ii) omnipotent, and so could presumably actualize a possible world in which life has meaning, and (iii) omnibenevolent, and so should want to actualize a world in which life has meaning because presumably, meaningful life is preferable to meaningless life. So, if this being exists, it would actualize a world in which life has meaning. Therefore, if the God of classical theism exists, then our lives have meaning; i.e., premise (2) is true.

Third, note that it is widely agreed by theists and atheists alike that if gratuitous suffering exists, God does not. Rowe (1979: 333), e.g., remarks that the incompatibility of God's existence and the existence of gratuitous evil "is . . . held in common by many atheists and nontheists. .. . [It] seems to express a belief that accords with our basic moral principles, principles shared by both the theists and nontheists." Likewise, Wykstra (1984, 141-142) states,

"The heart of [Rowe's incompatibility claim] is ... a conceptual truth unpacking part of what it means to call any being - not just any omniscient being - morally good. ... [Denying it] is tantamount to saying that God could allow some intense suffering either because he enjoys the sight of occasional suffering for its own sake, or because he is indifferent to it. It is hard to see how such a being could be meaningfully praised as a good God, worthy of our worship, our obedience, and not least - our trust. I take this to be a basic conceptual truth deserving assent by theists and nontheists alike." ${ }^{\prime 6}$

${ }^{6}$ While a large majority of philosophers of religion - whether they are theist, atheist, or agnostic - agree that the existence of God is inconsistent with the existence of gratuitous evil, it should at least be noted that there are some dissenters. For example, Peterson (2008), Hasker (1992), and van Inwagen (1995) argue that God and gratuitous evil are compossible. Kraay (2014) discusses some extant responses to van Inwagen's view and offers a novel objection to it. 
Penultimate Draft. Please cite the version forthcoming in the International Journal for Philosophy of Religion.

But also note that if our lives lack meaning, then our suffering is gratuitous. If our lives are ultimately meaningless, then any suffering we endure would be meaningless too (for if our suffering had meaning, then our lives would as well). If our lives lack meaning, there would be no greater meaning for our suffering either, and so it would be gratuitous. But then, given that we do suffer, and that God's existence and gratuitous suffering are not compossible, if God exists, our lives must have meaning.

Fourth, if our lives lack meaning, then creating us would be meaningless too; there would literally be no reason for God to create us if our lives lack meaning. So, if God does indeed exist and created or actualized the actual world, then the fact that God chose to actualize a world that contains us suggests that our lives have meaning, even if we do not or even cannot know what it is. That is, if God exists, then our lives have meaning.

We briefly address some possible objections. First, a theist might object that perhaps God merely makes it possible for our lives to have meaning; perhaps, e.g., we have to make that possibility actual somehow. God created the conditions in which all lives could have meaning and that is all a perfect being need do. If so, then it is possible for some lives to lack meaning even though God exists, and (2) is false. But again, if some lives lack meaning, then the suffering that those with meaningless lives endure is gratuitous, and gratuitous suffering is inconsistent with the existence of God.

Second, again, the consensus in the extant literature is that the meaning of life is distinct from (though perhaps related to) other positive features of an individual's life, e.g., wellbeing or happiness. But if so, perhaps an individual life could have certain positive features in such abundance - e.g., they are immensely happy - that God would still be justified in actualizing this 
Penultimate Draft. Please cite the version forthcoming in the International Journal for Philosophy of Religion.

person even if their life is meaningless. If so, then (2) is false; a life devoid of meaning is consistent with God's existence, and so God's existence is not sufficient for life to have meaning. However, one might wonder if an individual even could be immensely happy - or truly happy - if their life is meaningless. And one might wonder if God would actualize a meaningless life even if the life is a superficially happy one. And again, this life could contain no suffering at all, for any suffering that it would contain would be gratuitous, and gratuitous suffering is inconsistent with God's existence.

Third, one might object that perhaps it is logically impossible for all (or even some) lives to have meaning. If so, then God could - without blame - create lives that lack meaning, since God cannot be faulted for not doing the logically impossible. But it is difficult to see why it would be logically impossible for a life to have meaning. And in any event, again, if someone has a meaningless life, then their suffering is gratuitous, and the existence of God is logically inconsistent with gratuitous suffering. So, if indeed some of us in the actual world have meaningless lives, God does not exist. (2) is a conditional, so to falsify it, the antecedent would need to be true while the consequent is false; but this objection entails that the antecedent is false, so this objection could not demonstrate the falsity of (2).

Fourth, perhaps God has some justifiable reason, one that we do not or maybe even could not understand, for allowing at least some human lives to be meaningless. For example, one might object that according to skeptical theism, the moral truths and entailment relations that we know of are a small fraction of the moral truths and entailment relations that there are. However, God would know all of the moral truths and entailment relations that are logically possible to know. So perhaps one of these entailment relations that God knows but we do not know permits 
Penultimate Draft. Please cite the version forthcoming in the International Journal for Philosophy of Religion.

God to allow some meaningless human life. From God's perspective, (2) is false, and so it is in fact false, even though from our perspective (2) appears true. Skeptical theism is often advocated as a response to William Rowe's version of the evidential problem of evil (POE). In Rowe's version of the POE, one infers from the inscrutability of various evils (e.g. our inability to explain them) the conclusion that those evils are probably gratuitous. ${ }^{7}$ Skeptical theism blocks that inference because, on skeptical theism, our inability to explain an apparent evil does not imply that that evil probably cannot be explained. However, notice what follows for the meaning of life given skeptical theism. From our perspective, it seems like it would be less perfect for God to create lives that lack meaning. But God knows vastly more moral truths and entailment relations than we do. So from God's perspective, it might serve some greater good - of which we are unaware - to create lives that lack meaning. Our response is that there is something incoherent about this objection. If God creates meaningless human lives in the effort to bring about some greater good that could only be achieved through doing so, then our lives do indeed have meaning and purpose, namely, to play a role in bringing about this greater good. Also, it is far from clear that skeptical theism is true, so it is far from clear that any objection based upon can succeed. ${ }^{8}$

$7 \quad$ Rowe has defended this argument in a number of papers. See, for example, Rowe (1979; 1984; 1986; 1988; 1991; 1996).

$8 \quad$ There are several extant objections to skeptical theism. Ordinarily, theists say we are justified in trusting propositional information known only through divine revelation because God would not lie to us; yet, because skeptical theism leaves open the possibility that God might have morally obligatory reasons to lie to us, we are rendered unable to say how likely or unlikely God's lying would be (Wielenberg (2010); Hudson (2014)). There are further skeptical implications: Descartes ruled out the possibility that God would deceive us about the external world and the reliability of our senses, yet skeptical theism suggests that God could have a moral obligation, one beyond our comprehension, to globally deceive us (Wilks (2014)). Others have 
Penultimate Draft. Please cite the version forthcoming in the International Journal for Philosophy of Religion.

Fifth, we have never offered - or tried to offer - a positive account of what makes life meaningful. And one might worry that on some particular accounts of the meaning of life, it might be that God could be justified in creating a life that lacks meaning. But we suggest that our arguments are sufficiently general: they can succeed no matter what specific account of the meaning of life is true. Suppose that God exists and also suppose that any life that has feature $F$ is meaningful. Whatever $F$ might be, i.e., whatever particular account of the meaning of life is true, having $F$ is necessary and sufficient for life to have meaning. And now suppose that there can be a life without $F$. But then the suffering in this life would be gratuitous and God cannot allow gratuitous suffering. So if God exists, then no matter what $F$ is, i.e., no matter what particular account of the meaning of life is true, then all lives must have $F$. No matter which theory of the meaning of life is true, if God exists, God is sufficient for life to have meaning. One might worry that perhaps God could use a meaningless life to bring about a greater good; if so, then the suffering in this life is not gratuitous, and so God is perhaps justified in creating that life, yet this person's life is still meaningless. But it seems that if we are in a universe created by God, then if God uses a life to bring about a greater good, that life is not meaningless; the person in question, e.g., serves an important purpose, and so their life has meaning after all.

But if (1) and (2) are true, then,

(3) If God exists, then no lives are meaningless.

Of course, (1) and (2) entail (3) with hypothetical syllogism. The existence of God would guarantee that our lives have meaning, whatever that meaning might be. God's existence is a

argued that skeptical theism destroys the possibility of moral deliberation (Piper (2007); Sehon (2010)) or of inductive inference (Hasker (2010)). 
Penultimate Draft. Please cite the version forthcoming in the International Journal for Philosophy of Religion.

sufficient condition for our lives to have meaning. But while God's existence is sufficient for life to have meaning, is God the source of this meaning, even assuming that God exists? Do our lives have meaning simply because - or only if - God exists? Is God's existence necessary for life to have meaning? We now turn to this question.

\section{GOD CANNOT BE THE SOURCE OF THE MEANING OF LIFE}

We argue that if life has meaning, then God is not the source of this meaning.

\section{Argument One}

Posit two possible worlds: $G$ and $N G$. Both worlds $-G$ and $N G$ - are perfect duplicates of each other, but with one exception: God exists in $G$ but God doesn't exist in $N G$. Moreover, both worlds - apart from the existence or non-existence of God - are perfect duplicates of the actual world. To rephrase this: we either exist in $G$ or $N G$. If God exists, then we exist in $G$, but if God does not exist, then we exist in $N G$.

Here, we are agnostic as to whether we are in $G$ or $N G$. So suppose, for the moment, that both worlds are at least epistemically possible. That is, given the current state of knowledge, we might, for all we know, exist in $G$, or we might, for all we know, exist in $N G .^{9}$ Furthermore, assume that God is somehow the source of the meaning of life; God is necessary for life to have meaning; but then if there is no God, life cannot have meaning. So, in $G$, our lives have

9 Someone might object that if God exists, God exists necessarily. So there cannot be a possible world - like $N G$ - in which God does not exist. But this objection conflates metaphysical and epistemological possibility. God's existence or non-existence might be metaphysically necessary, but that is a separate issue from our knowledge of God's existence, and so from epistemic possibility. Another way that we could have constructed the argument, which we do not pursue here, would be in terms of counterpossibles. 
Penultimate Draft. Please cite the version forthcoming in the International Journal for Philosophy of Religion.

meaning; if God exists, then since the existence of God is sufficient for life to have meaning, our lives are meaningful. But in $N G$, our lives do not have meaning; we have assumed that God is the source of the meaning of life and there is no God in $N G$, so in $N G$, our lives are meaningless. Again, by hypothesis, the two worlds are duplicates aside from the existence or non-existence of God. So, two lives, one in $G$ and one in $N G$, can be qualitatively identical, yet one has meaning and the other does not. So the meaning of life does not depend on or supervene on or is not grounded in or determined by the actual content of our lives. The meaning of life does not depend upon any experiences that we have, on the nature of or content of our thoughts or beliefs, on any of our actions or accomplishments, on how moral or immoral we are, or on any relationships we form. We can do nothing to imbue our lives with meaning: two people can be complete duplicates yet only one of these lives might have meaning. Indeed, the meaning of life would not even depend upon any beliefs about or attitudes towards God: someone could have the same beliefs and attitudes towards God in both worlds, yet this is not sufficient for life to have meaning, since one person's life would have meaning and the other's wouldn't. Yet, it seems implausible to completely divorce the meaning of life from anything concerning the content of particular lives. So our assumption - that God is the source of the meaning of life - is problematic.

Theists might object that $G$ and $N G$ are not in fact identical in every respect, so the above argument fails. Classical theists often posit an interventionist God who, e.g., created the universe and who might be responsible for (some of) the revelations and miracles described in the major monotheistic religions. Perhaps at least some of God's interventions are necessary to endow one's life with meaning? However, most theists and presumably all non-theists agree that 
Penultimate Draft. Please cite the version forthcoming in the International Journal for Philosophy of Religion.

there are individuals in whose lives God has never intervened. Thus, it is highly plausible that there are at least some individuals in $G$ and $N G$ who are identical in all relevant respects. And if the presence of divine intervention in one's life were necessary for one's life to have meaning, then there would be some individuals in both $G$ and $N G$ whose lives do not have meaning. But again, since God is sufficient for life to have meaning, every life must be meaningful in $G$. That is, we have reached a contradiction; therefore, divine intervention in one's life cannot be necessary for that life to have meaning.

Theists might respond that $G$ and $N G$ differ in another way: there would be an afterlife in $G$, but no afterlife in $N G$. Without an afterlife, our lives would be short and finite; compared to eternity, our short lives would be diminished to complete insignificance. This response is implausible for two reasons. First, nothing about the non-existence of God logically entails that there is no afterlife. There is an epistemically possible world in which there is both an afterlife and in which God does not exist. Because human lives might be eternal in such a world, on the theist's reasoning, life would have meaning. Therefore, given the theist's premises, life can have meaning without God. That is, God would not be necessary for life to have a meaning, which is the very claim we are trying to establish. Second, it is difficult to see why the duration of something should reduce whatever meaning it has. For example, a vacation might last only a few days, but might still be just as meaningful to the vacationer as a long vacation. Some might have different intuitions than us about the value of a short-lived experience, but we see no reason to prefer their intuitions over ours. Indeed, it seems there are some events that mean more because of their brevity; many would, e.g., look back to their undergraduate days with less fondness if one was an undergraduate for 20 years. 
Other possible objections involve drawing distinctions that are often glossed over when discussing the meaning of life. We can distinguish between:

(i) The significance we attribute to our own lives;

(ii) The purpose we devote our lives to;

(iii) The significance God attributes to our lives;

(iv) The purpose for which God created us.

For convenience, call this the "four-fold distinction." The theist might claim that while (i) and (ii) can exist in both $G$ and $N G$, (iii) and (iv) can exist only in $G$. The theist might state that without (iii) and (iv), our lives will not have any ultimate or cosmic significance or purpose, so without God, there can ultimately be no meaning to our lives after all. Or the theist might object that the meaning of our lives can only originate in some source external to ourselves, a source that is perfect, and so this source must be God. For instance, maybe God created us for some purpose, and our lives have ultimate significance only insofar as we fulfill this purpose. We now consider the possibility that the meaning of life originates in some external source.

\section{Argument Two}

Suppose that human life has meaning. If so, there are two possibilities. First, human lives have intrinsic meaning. That is, a human life is meaningful in and of itself. A life's meaning is not dependent upon anything external to itself. So, e.g., if there was a possible world that contained nothing aside from a single human being, the human life would still have meaning. Second, human lives have meaning, but this meaning is not intrinsic to that life. It depends, rather, on something external to people; people must stand in some relationship with something external to 
themselves for their lives to have meaning. So, e.g., if there was a possible world that contained nothing aside from a single human being, that human life would not have meaning. These are indeed the only two options; given the assumption that life has meaning, then either that meaning is intrinsic to lives or not (and so is extrinsic); indeed, this is an instance of excluded middle.

So, suppose that human lives have meaning in and of themselves; the meaning of life does not depend upon anything external to people. But then, life would have meaning even if God did not exist; the meaning of life could not be dependent upon God; God would not be necessary for life to have meaning. ${ }^{10}$ However, now suppose that the meaning of life is dependent upon something external to us. Indeed, suppose that the meaning of life is dependent upon some relation that we stand in with God. But note that God's existence is sufficient for life to have meaning (see above). So, lives in a possible world in which God exists will have meaning no matter what. But then any life - regardless of the nature or content of that life - will have meaning. So, the meaning of life will not depend upon any of our beliefs, actions, and so on. And again, this is implausible, which suggests that the meaning of life is not dependent upon God. So, given that life has meaning, either this meaning is intrinsic to us or not; but either option suggests that God is not necessary for life to have meaning. Therefore, God is not necessary for human life to have meaning.

10 A theist might object that even if our lives have intrinsic meaning, this does not imply that this meaning is independent of God. God creates us, so in a sense, this meaning that lives intrinsically have still depends upon God for its existence (in a causal sense). But we suggest that if lives can have meaning intrinsically, then these lives could have been caused by something aside from God (say, some purely naturalistic process) and still retain their meaning. In which case God is not necessary for life to have meaning. 
Penultimate Draft. Please cite the version forthcoming in the International Journal for Philosophy of Religion.

To elaborate, suppose that an external source - specifically, God - is necessary for life to have meaning. And recall the four-fold distinction discussed above. Given the four-fold distinction, there are four possibilities: (a) the purpose we devote ourselves to matches the purpose for which God created us; (b) the purpose we devote ourselves to does not match the purpose for which God created us; (c) the significance we attribute to our lives matches the significance God attributes to us; or (d) the significance we attribute to our lives does not match the significance God attributes to us. But as we now argue, each possibility is problematic. This suggests that God is not necessary for life to have meaning.

First, suppose that (a) the purpose we devote ourselves to matches the purpose for which God created us. But it is not clear that simply following God's purpose for us would be sufficient to imbue life with meaning. For example, even though a child might be created by her parents for some particular purpose, the child might have no obligation to fulfill this purpose. If Sue learns her parents created her solely for the purpose of harvesting her organs for a sibling, Sue has no obligation to fulfill this purpose. There are many differences between God and human parents, and perhaps there is some relevant difference in virtue of which God's purposes for us should be our purposes for ourselves, but it is difficult to see what that relevant difference could be.

Moreover, God's role as creator does not, by itself, guarantee that the purpose we find most satisfying is the purpose for which God created us. Perhaps it would be much more satisfying if we chose our purpose for ourselves than if our purpose was preselected for us? If so, given a choice between a world in which God preselected a purpose for us and one in which we chose our own purpose, we would prefer the latter. Yet, God, as a perfect creator, would 
Penultimate Draft. Please cite the version forthcoming in the International Journal for Philosophy of Religion.

know which purpose we would find most satisfying to devote our lives to; thus, given God's benevolence, it seems plausible that God would create us so that, constitutionally, we would have a desire to pursue the ends for which God created us and that those ends brought about some good for us. Nonetheless, in $N G$, our lives would be devoted towards identical ends. Thus, whatever goods God accomplished in virtue of creating us in $G$ would also be actualized in $N G$, or in the absence of God; but then God would not be necessary for life to have meaning. And it is difficult to understand why God's experiencing those goods would be necessary for our lives to have meaning, unless God created us as means for God's ends, irrespective of what our desires are. Yet it is unlikely that God, a perfectly good being, would create us for God's ends, irrespective of our desires, because this would involve treating creatures as mere means instead of as ends unto themselves. It is even more difficult to see how this would be required for our lives to have purpose. In short, (a) is problematic.

Now consider (b): God's purposes do not match our purposes. So, God has created us for some end or ends, yet we are constituted to desire some other ends. This is incoherent. Ceteris paribus, given the choice of creating $x$, which accomplishes some collection of ends $C$, and $y$, which does not accomplish $C$ as well as $x$ accomplishes $C$, a rational agent who wishes to accomplish $C$ would always prefer creating $x$ over $y$. The more intelligent and knowledgeable the agent, the more the agent would be aware of how successful any possible creation would be at accomplishing $C$; and the more powerful the agent, the more the agent would be capable of creating what they prefer. Thus, God, as a perfectly rational and capable being, would create whatever it is that best brings about the ends God aims for. So, if there were creatures who were 
Penultimate Draft. Please cite the version forthcoming in the International Journal for Philosophy of Religion.

constructed that found pursuing ends other than God's to be maximally satisfying, there would be a contradiction between God's nature and God's creation.

The preceding argument - that it is incoherent for God to create creatures whose purpose does not match God's - is an instance of a dysteleological argument. Dysteleological arguments hold that, while natural theologians have posited a meeting of ends and purposes in their observations of nature indicative of design, many natural structures are not well designed and fail to be optimally suited for their functions. For example, Gould (1978) argues that the panda's thumb is not well designed for the function the thumb performs for the panda. One objection to dysteleological arguments is that they require us to know what God's intentions were. If God intended to create a sub-optimal thumb for the panda, then the fact that the thumb possesses a sub-optimal thumb is not evidence contrary to design after all (Sober 2008: 127-128). Moreover, it seems plausible that design can be detected even when we do not know what the intentions of the designer were. For example, archaeologists can infer that artifacts were produced by agents even if we do not know the agent's intentions. For instance, artifacts might have been produced for religious rituals about which we know nothing. But this response to other dysteleological arguments cannot succeed as a response to our dysteleological argument. For while we do not know what purpose, if any, God might have had for the panda's thumb, we have postulated - by hypothesis - a case in which humans fail to accomplish the ends for which God created them. Cases in which we are so constituted that our purposes fail to match God's are incoherent and therefore need no further consideration.

Now consider (c): the importance God attributes to us matches the importance we attribute to ourselves. But in this case, we would attribute the same importance to our lives 
Penultimate Draft. Please cite the version forthcoming in the International Journal for Philosophy of Religion.

regardless of whether we lived in $G$ or $N G$. Therefore, it is difficult to see what difference God would make in this scenario.

Finally, consider (d): the importance God attributes to us does not match the importance we attribute to ourselves. If so, there are two possibilities: either we attribute a greater importance to ourselves than God or we attribute less importance to ourselves than God. Assuming that we attribute more importance to ourselves than God, our lives would be imbued with a deep sense of importance (even if inappropriate) in both $G$ and $N G$. So, it is difficult to see why we would need to be in $G$ as opposed to $N G$ for our lives to have meaning. Furthermore, there are individuals, such as the severely depressed, who attribute very little, if any, importance to their life; surely, the theist would want to say that God values such people more than they value themselves. But if so, then not all humans value their lives more than God values their lives.

But assuming that we attribute less importance to ourselves than God, we arrive at a variant of the problem of evil. For God to create beings that tend to regard their lives as less meaningful than they are would involve God creating beings who suffer more than they need to (i.e., if they had known the actual meaningfulness of their lives, they would suffer less). This would be gratuitous suffering; and again, God's existence is not consistent with gratuitous suffering. And as with the dysteleological argument, common objections to the problem of evil - such as Skeptical theism - constitute inappropriate responses. Therefore, it is difficult to make sense of the scenario in which we attribute less importance to ourselves than God would have. But then (d) is problematic. 
In sum, if we assume that God is necessary for life to have meaning, there are four possibilities. But each possibility faces various issues; this suggests that God is not necessary for meaningful human life.

\section{Argument Three}

We now offer a third argument for doubting that God is a necessary condition for meaningful human life.

Suppose that God is necessary for our lives to have meaning. But then, the meaning of life must arise through some sort of relation, whatever it might be, that we stand in with respect to God; for if no such relation between us and God is needed for life to have meaning, then our lives could have meaning independently of God. For example, this relation that we stand in with God could be some or all of the following: our lives obtain meaning through belief in God, or through following God's plan for us, or by following the commandments of God, or through actions related to God, or through some other means. The important point is that, given our assumptions, our lives become meaningful through a relation - whatever it might be - between us and God. The question is: for life to have meaning, do we also (i) need to be conscious of this relationship with God or (ii) not? Do we have to be aware of this relationship and, say, perform actions in accordance with it, for example, for our lives to have meaning?

Suppose (i); we do have to be aware of this relation that we stand in with God for life to have meaning. Perhaps we have to act certain ways given this relation for life to have meaning (e.g., we have to worship God, or go to church, we have to at least know that God exists, or whatever), or perhaps just a simple awareness of this relation is sufficient. However, even 
Penultimate Draft. Please cite the version forthcoming in the International Journal for Philosophy of Religion.

assuming that God exists, it seems that not everyone can be aware of their relation with God, and indeed, for some, this lack of knowledge is not their fault; that is, there appear to be cases of "blameless non-belief." For example, some, simply because of where or when they were born, have little or even no chance to become aware of their relationship with God. As Maitzen (2006) convincingly argues, it is difficult to understand the geographic distribution of theism if an all-powerful God exists and desires a relationship with all humans; the problem is that some are born in areas (e.g., predominately atheistic societies) where it is unlikely they will become theists. And what of those who were born before monotheism became widespread? In short, because of personal circumstances that were beyond their control, some will not become aware of their relationship with God, even assuming that this relationship exists. Furthermore, even among those who live in highly religious cultures, some individuals are less cognitively disposed towards theism than others. Recent studies in cognitive science demonstrate that belief in God (or, more generally, in supernatural entities) correlates with theory of mind. A larger percentage of those who possess a diminished theory of mind (hypoactive agent detection) - such as autistic individuals - are non-theist (Caldwell-Harris, Catherine, et al., 2009; Gervais 2013 - especially, p 18), while those with an exaggerated theory of mind (hyperactive agent detection) - such as schizophrenic individuals (Gervais 2013, pp 18-19; Crespi \& Babcock, 2008) - tend to overdetect agency and teleology in the world, and tend to believe in God with above average frequency. It is difficult to understand how a loving and all-powerful God, who presumably desired relationships with all humans, would design humans with differing cognitive capacities for forming relationships with God. In short, if the meaning of life depends upon an awareness of our relationship with God, then instances of blameless non-belief would entail that, at 
minimum, God treats people differently based on things that were outside of their control, a deep injustice. God cannot be unjust, so God probably doesn't exist given (i). Moreover, if awareness of our relationship with God is necessary for life to have meaning, and many - through no fault of their own - will not be aware of this relationship, then these people's lives will lack meaning. But if their lives lack meaning, then their suffering is gratuitous. And the existence of gratuitous suffering is inconsistent with the existence of God, so again, given (i), God cannot exist. Even the theist should reject (i).

The alternative is that (ii) we do not need to be aware of our relationship to God for life to have meaning. So now, those who - through no fault of their own - are not aware of this relation can have meaningful lives. They stand in the necessary relation to God for life to have meaning; they are simply unaware of it. But now, it is difficult to see why anyone should bother being religious. If the meaning of life is not enhanced in any way from, say, even being aware of the existence of God, let alone from acting on the knowledge of our relationship with God, then religion adds no meaning to our life. So the idea that God is the source of the meaning of life is problematic, even for theists, because it seems to entail either that (a) God does not exist or (b) we might as well be indifferent to religion.

\section{Argument Four}

Consider Divine Command Theory (DCT): moral facts are (somehow) reducible to God's commands. And consider a problem with DCT, the Euthyphro Dilemma: is $x$ moral because God commands $x$ or does God command $x$ because it is moral? If the former, then the fact that $x$ is moral is arbitrary; had there been any further facts that explained God's command to do $x$, 
Penultimate Draft. Please cite the version forthcoming in the International Journal for Philosophy of Religion.

those facts would have been the actual reason that $x$ was moral and not God's command. Yet if morality were arbitrary, God could command us to commit heinous acts and it would be morally obligatory for us to commit them, which seems wrong. But if the latter, then $x$ is moral independently of God's commands and DCT is false.

A parallel argument can be constructed for the meaning of life. One can ask, "do our lives have meaning because God decrees that they do, or do our lives have meaning independently of God?" If our lives have meaning independently of God, then they do not have meaning simply because God decrees that they do; God would not be necessary for life to have meaning. But our lives probably do have meaning independently of God, for if our lives have meaning only because God says so, a number of difficulties (that parallel those faced by DCT) arise: God could arbitrarily decide to change what things have meaning and what things do not; meaning will (arguably) not be objective; it is puzzling how something can have meaning simply because an authority says it does; God cannot be praised for being significant "meaningful" and so on. Of course, this argument cannot show - and does not try to show - that God does not exist; it simply argues that if there is a God, God is not what gives our lives meaning (if our lives are in fact meaningful). So, if our current lives have meaning, then they have meaning whether God exists or not, and so should also have meaning if atheism or naturalism is true. That is, God is not a necessary condition for our lives to have meaning.

However, to defend DCT, some theists have responded that the Euthyphro Dilemma is a false dichotomy. It might be that these theistic defenses of DCT succeed, but even assuming that they do, this does not imply that they can simply be adapted to defend the claim that God is necessary for the meaning of life, as we now suggest. There are views according to which moral 
Penultimate Draft. Please cite the version forthcoming in the International Journal for Philosophy of Religion.

facts require a perfect standard of goodness. Just as the length of the meter is determined by the length of a standard piece of metal, so too goodness is grounded in a perfect person who maximally exemplifies goodness (see, for example, Craig (1997); Alston (2002)). Likewise, perhaps for our lives to have meaning, meaningfulness must be grounded in the standard of some being whose life is perfectly meaningful. Only God could have a perfectly meaningful life, so only God could ground life's meaningfulness. This possibility might avoid Euthyphro Dilemma style objections; e.g., on this view, God could not arbitrarily decide to make things meaningful. Instead, meaning is grounded in God's nature as the standard of meaningfulness. But is this view plausible? God's life would be perfectly meaningful without any external source of its meaningfulness. But then it is difficult to see why we would need an external source of meaning if God does not require one. In other words, if a perfectly meaningful life does not require some external measure, then why do less perfect lives require an external measure?

But there are other ways defenders of DCT have tried to ground morality in God. One view claims that properties in general are (somehow) grounded in God; so moral properties, qua properties, are grounded in God. Meaningfulness might be a property; so perhaps this view can ground meaningfulness in God and overcome our fourth argument? One suggestion to ground properties (and so moral properties) in God identifies properties with God's essence (see, for example, Leftow (1990)). According to classical theism, God cannot depend upon anything else (i.e., aseity); thus, God cannot depend upon God's properties in the way that creatures do. Indeed, God is the unique necessarily existent being that depends upon nothing else. Yet, God cannot be said to create God's properties because God cannot be explanatorily or causally prior to those properties. One proposal is to identify all of God's properties with God's essence: divine 
Penultimate Draft. Please cite the version forthcoming in the International Journal for Philosophy of Religion.

simplicity. It is difficult to make sense of God's properties on divine simplicity, but suppose the theist can make sense of this. But note that, by 'property', we do not mean instances of properties, but what platonists might have called the Forms. If God's properties were merely instances of some collection of universals (or abstracts), then God would depend upon those universals (or abstracts). Again, moral properties are properties. Thus, on this view, moral properties would be identical to God's essence. If so, then it is not God's commandments that make it wrong to murder (for example) but God's essential goodness. The commands God issues might still create moral obligation, but they cannot be inconsistent with God's nature and so are not arbitrary. On this view, which would arguably overcome at least some of the traditional objections to DCT, God's essence is identical to properties; so perhaps the meaningfulness of life is a property of life; and thus, meaningfulness would be identical to God's essence. So, it would not be arbitrary that life is meaningful because meaningfulness would be grounded in the objective, eternal, and necessary essence of God. However, given that meaningfulness would be identical to God's essence and that God's essence does not require a creator, the theist would be committed to the view that meaningfulness does not require a creator. But then meaningfulness might as well exist, uncreated, without God as a platonic form. In which case God is not necessary to ground meaning.

Other attempts to ground properties in God claim that properties are ideas in God's mind. Given that God (and therefore God's ideas) is external to space and time, eternal, and necessary, these views can explain why properties are external to space and time, eternal, and necessary. But can views of this sort ground meaningfulness as an idea in God's mind in such a way that Euthyphro Dilemma type objections can be avoided? Presumably, God could either conceive of 
Penultimate Draft. Please cite the version forthcoming in the International Journal for Philosophy of Religion.

an idea of meaningfulness arbitrarily or for some reason $R$. But if God conceives of the idea because of $R$, then $R$, and not God, is why God conceived of it; $R$ makes the idea meaningful and this is why God conceives of it; so it is meaningful independently of God, or else arbitrarily meaningful. Moreover, it is difficult to understand the order of explanation in a view that posits meaningfulness as an idea in God's mind. On the one hand, the notion that God's life produces meaning seems comprehensible. But on the other hand, in order to explain God's life as meaningful, meaningfulness would have to be explanatorily independent to God's life. Yet, on a view in which meaningfulness is an idea in God's mind, meaningfulness would be explanatorily dependent on God's life. Thus, such views would incorrectly reverse the order of explanation; they place the explanandum before the explanans; see, e.g., Morriston (2011: 21-22), who makes a parallel argument.

\section{CONCLUDING REMARKS}

We argued that God is sufficient, though not necessary, for human life to have meaning. These claims, taken in isolation, are consistent with both theism and atheism. So taken in isolation, they cannot count as an argument for or against theism or atheism. However, these claims are not wholly unrelated to questions concerning God's existence. For example, one can combine claim (1) with an additional claim to form a novel argument for atheism. The "argument from meaninglessness" is:

(1) If God exists, then all lives have meaning. (Premise, defended above)

(2) There is or has been at least one human life that lacked meaning. (Premise) Therefore, 
Penultimate Draft. Please cite the version forthcoming in the International Journal for Philosophy of Religion.

(3) God does not exist. (Modus Tollens $1 \& 2$ )

That is, if it could be shown that even just one life lacks (or lacked) meaning throughout human history, then God does not exist. Note that this argument is not logically equivalent to the problem of evil. For example, it seems possible that one could suffer greatly yet have a meaningful life; or one could not suffer yet have a meaningless life. Moreover, arguably, given theism it is not merely that all lives must have meaning; but this meaning must be an "appropriate" one, one worthy of the creation of a perfect being. It does not seem implausible that some people, e.g., John Wayne Gacy, have lived lives that lack such an "appropriate" meaning.

Furthermore, some claim that our lives could have meaning only if God exists. Indeed, sometimes theists make this claim, and then argue that since life has meaning, God exists. But such arguments backfire and actually entail the falsity of theism. For if God could be the only thing that could give our lives meaning, but God could not be the source of the meaning of life, as we argued above, then our lives do not have meaning. And since God could not create meaningless human life, God cannot exist. In sum, while our arguments are not directly related to questions concerning the existence of God, they have some bearing on them insofar as (i) they suggest the possibility of a novel argument against theism and (ii) suggest that one extant argument for theism cannot succeed.

Logically speaking, there are only so many positions one can take on the relationship between God and the meaning of life. One might claim that (a) God exists or (b) God does not exist. And given (a) or (b), one might claim that (c) life has meaning or (d) life is meaningless. So there are four possible combinations: (1) (a) \& (c), (2) (a) \& (d), (3) (b) and (c) and (4) (b) 

Religion.

and (d). But if the arguments above are correct, position (2) can be eliminated: if God is sufficient for the meaning of life, then God's existence is inconsistent with meaningless human life. Moreover, since God is not necessary for meaningful human life, (3) remains a live option. Of course, since God's existence entails that our lives are meaningful, the theist must endorse (1). So, perhaps given theism, something like the following picture is true: God surveyed the logically possible worlds, trying to decide which world to actualize. Some worlds contain life; and in some of these worlds, life has meaning, while perhaps in others, it does not. So, e.g., in one world, a man is ceaselessly pushing a boulder up a hill only to have it roll back down the hill again; this life might have meaning and might not. But the meaning (or lack thereof) of these lives is there independently of God. God is not necessary for the meaning of life. But God is good and so on, so God will choose to actualize a world in which life has meaning. We are not saying this picture is true; we are simply trying to determine what the theist might claim given the conditionals above. At any rate, on this picture, God's existence is sufficient for life to have a meaning. Moreover, given atheism, position (3) or (4) is true. It might be that the actual world simply exists for no reason, or perhaps there is a reason for the existence of the actual world that does not involve God (e.g., the world exists because of various laws of physics). But whatever the reason, it might just so happen that we exist in a world in which our lives have meaning. Again, God's existence is not necessary for life to have a meaning, so atheism does not necessarily preclude us from having meaningful lives. ${ }^{11}$

\footnotetext{
11 We would like to thank an anonymous referee for immensely helpful comments on an earlier draft.
} 
Penultimate Draft. Please cite the version forthcoming in the International Journal for Philosophy of Religion.

References

Affolter, J. (2007). “Human Nature as God's Purpose”, Religious Studies, 43: 443-55.

Alston, W. (2002). "What Euthyphro Should Have Said”. In William Lane Craig (ed), Philosophy of Religion: A Reader and Guide. Edinburgh: Edinburgh University Press, 283-289.

Bond, E. J. (1983). Reason and Value. Cambridge: Cambridge University Press.

Brown, D. (1971). "Process Philosophy and the Question of Life's Meaning”, Religious Studies, 7: 13-29.

Camus, A. (1955). The Myth of Sisyphus. J. O'Brian (tr.). London: H. Hamilton.

Caldwell-Harris, C., Murphy, C. F., Velazquez, T., \& McNamara, P. (2011). "Religious belief systems of persons with high functioning autism", In Annual Meeting of the Cognitive Science Society, Boston, MA.

Cottingham, J. (2003). On the Meaning of Life. London: Routledge.

Craig, W. (1994) "The Absurdity of Life Without God", repr. in The Meaning of Life, $2^{\text {nd }}$ Ed., E. D. Klemke (ed.), New York: Oxford University Press, 2000: 40-56.

Craig, W. (1997). "The Indispensability of Theologicaly Meta-ethical Foundations For Morality”. Foundations 5: 9-12.

Crespi B. J., \& Badcock, C. (2008) "Psychosis and autism as diametrical disorders of the social brain". Behavioral and Brain Sciences 31, 284-320.

Gervais, W. (2013). "Perceiving Minds and Gods: How Mind Perception Enables, Constrains, and Is Triggered by Belief in Gods". Perspectives on Psychological Science, 8 (4): 380-394.

Gordon, J. (1983). "Is the Existence of God Relevant to the Meaning of Life?" The Modern Schoolman 60: 227-46.

Gould, S. J. (1978). “The Panda's Peculiar Thumb”. Natural History 87 (Nov.): 20-30.

Haber, J., (1997). “Contingency and the Meaning of Life”, Philosophical Writings, 5: 32-44. 
Penultimate Draft. Please cite the version forthcoming in the International Journal for Philosophy of Religion.

Hasker, W. (1992). “The necessity of gratuitous evil”, Faith and Philosophy 9:23-44.

----. (2010). “All Too Skeptical Theism”. International Journal for Philosophy of Religion 68: $15-29$.

Hudson, H. (2014). “The Father of Lies?”. Oxford Studies in Philosophy of Religion. Jonathan Kvanvig, ed. Oxford: Oxford University Press. 147-166.

Kahane, G. (2014). “Our Cosmic Insignificance.” Nous 4 (48), 745-772.

Kahane, G. (2012). “The Value Question in Metaphysics.” Philosophy and Phenomenological Research 85: 27-55.

Kahane, G. (2011). "Should We Want God to Exist?” Philosophy and Phenomenological Research 82: 674-696.

Kraay, K. (2014). “Peter van Inwagen on Gratuitous Evil”. Religious Studies 50: 217-234.

Kraay, K. and Dragos, C. (forthcoming). “On Preferring God's Non-Existence.” Canadian Journal of Philosophy.

Leftow, B. (1990). “Is God an Abstract Object?”. Nous 24: 581-598.

Levine, M., (1987). “What Does Death Have to Do with the Meaning of Life?" Religious Studies, 23: 457-65.

Mawson, T. (2012). "On Determining How Important it is Whether or Not there is a God." European Journal for Philosophy of Religion 4: 95-105.

Maitzen, S. (2006). "Divine hiddenness and the demographics of theism". Religious Studies 42: $177-191$.

Metz, T. (2013). Meaning in Life. Oxford: Oxford University Press.

-----. (2013). "The Meaning of Life." The Stanford Encyclopedia of Philosophy (Summer 2013 Edition), Edward N. Zalta (ed.), URL = $<$ http://plato.stanford.edu/archives/sum2013/entries/life-meaning/>.

Morriston, W. (2011). "God and the ontological foundation of morality". Religious Studies, $48,15-28$. 
Penultimate Draft. Please cite the version forthcoming in the International Journal for Philosophy of Religion.

Nozick, R. (1981). Philosophical Explanations, Cambridge, MA: Harvard University Press.

Peterson, M. (2008). "C. S. Lewis on the necessity of gratuitous evil” in D. Baggett, G. Habermas, and J. Walls (eds.) C. S. Lewis as Philosopher: Truth, Goodness, and Beauty. Downers Grove, IL: InterVarsity Press.

Rowe, W. (1979) “The Problem of Evil and Some Varieties of Atheism”. American Philosophical Quarterly, 16 (4), 335-41.

-- (1984) "Evil and the Theistic Hypothesis: A Response to S.J. Wykstra”. International Journal for Philosophy of Religion, 16, 95-100.

-- (1986) “The Empirical Argument from Evil”. In Robert Audi \& William Wainwright (Ed), Rationality, Religious Belief and Moral Commitment. Ithaca: Cornell University Press.

-- (1988) “Evil and Theodicy”. Philosophical Topics, 16: 119-32.

-- (1991) “Ruminations about Evil”. Philosophical Perspectives, 5, 69-88.

-- (1996) “The Evidential Argument from Evil: A Second Look”. In Daniel Howard-Snyder (Ed), The Evidential Argument from Evil. Bloomington: Indiana University Press.

Sehon, S. (2010) "The Problem of Evil: Skeptical Theism Leads to Moral Paralysis". International Journal for Philosophy of Religion, 67: 67 - 80.

Singer, P. (1993). Practical Ethics, $2^{\text {nd }}$ Ed. New York: Cambridge University Press.

Sober, E. (2008). Evidence and Evolution: the Logic Behind the Science. New York: Cambridge University Press.

van Inwagen, P. (1995). "The magnitude, duration, and distribution of evil" in God, Knowledge, and Mystery. Ithaca, NY: Cornell University Press. 96-122.

Wainwright, W. (2013). "Concepts of God". In The Stanford Encyclopedia of Philosophy. (Spring 2013 Edition), Edward N. Zalta (ed.). URL = $<$ http://plato.stanford.edu/archives/spr2013/entries/concepts-god/>. 
Penultimate Draft. Please cite the version forthcoming in the International Journal for Philosophy of Religion.

Wilks, I. (2013) “The Global Skepticism Objection to Skeptical Theism”, in The Blackwell Companion to the Problem of Evil (eds J. P. McBrayer and D. Howard-Snyder), John Wiley \& Sons, Ltd, Oxford.

Wolf, S. (1997). "Happiness and Meaning: Two Aspects of the Good Life." Social Philosophy and Policy 14: 207-25.

Wykstra, S. (1984). "The Humean Obstacle to Evidential Arguments from Suffering: On Avoiding the Evils of 'Appearance'". International Journal for the Philosophy of Religion. 16 (1984): 138-160. 